\title{
REFLECTIONS ON THE LAST 50 YEARS OF THE LAW AND LAW SCHOOL
}

\author{
Sir Michael Hardie Boys*
}

This paper was presented as a lecture on "Capital Law School Day" organised by the New Zealand Institute of Advanced Legal Studies to mark the occasion of the centenary of the Faculty of Law, Victoria University of Wellington in 1999.

Earlier this year the Chief Justice and I joined a large number of Aucklanders in celebrating another centenary, the one hundredth birthday of Lord Denning, born just three months before this Law School. He knew we were to do that, but he did not learn of what was said and done in his honour, for within a few days he died. As we this week celebrate the one hundredth birthday of the Law School, we can be confident that it is far from imminent demise. On the contrary, it is as vigorous and as productive as ever it was, truly a capital law school. And so it is entirely in order for me, at this first opportunity I have had, to offer congratulations to today's Dean and staff, and to thank them for theirs, the most recent contribution to our 100 year history. At the same time we will all, I know, want to pay tribute to those who have gone before them: those who first laid the foundations on which legal education in this University has been built and those who in successive generations have upheld their standards and given reality to their dreams. Thousands of lawyers, be they teachers, practitioners or engaged in other occupations, owe an immense debt to this University and particularly to this Law School; and so does the whole nation, for the service given in countless ways by those who have learned here not only their law but also its proper working out in community and national life.

It has been a sobering thought, for me at least, to realise that I entered law school at one point of what has now been its 100 year history.

\footnotetext{
* Governor-General of New Zealand.
} 
I was then a little less than 17 years old, too young to be sure that I really wanted to be a lawyer, too young to really appreciate what the law was all about. I suppose I finally grew out of those uncertainties, but nonetheless what has become of me since, leading up to my being invited to launch this Seminar, has continually mystified me and often alarmed me. That is particularly true of today's invitation to contribute to the general theme of the future development of the law and of the Law School. It will soon be four years since I sat in a Court and even the present state of the law is something about which I am far from confident. I am also acutely aware that others who are to follow me are greatly more qualified than I to pass judgement on both topics. After all, I no longer exercise an independent judgement - although I enjoy the thought that like the razor strap my father kept in the hall cupboard, I could if I really had to. But short of a crisis precipitating that need, I do as I am advised, which is a constitutional euphemism for doing as I am told.

However, it was later suggested, very wisely I thought, that I might include some of my recollections of those now far-off Law School days. It has been an interesting exercise to dust off the cobwebs of memory and think back half a century, which incidentally takes us to the virtual beginning of the Denning era. There is a nice coincidence here, for there has been almost an explosion in the law since then, some of it without doubt detonated by him. So may I take you back 50 years, before offering some very general observations, by way of an opening gambit really, on today's principal themes.

In 1949 the Law School was part of Victoria University College, itself a constituent of the University of New Zealand. The Chancellor was Sir David Smith, just retired from 20 years' service as a Judge of what was then known as the Supreme Court. The Principal (Vice-Chancellors were a later arrival) was Sir Thomas Hunter, of whom J C Beaglehole wrote that no man ever did more for education as a social and liberalising force in New Zealand.

My attempts to find out how many students were at Victoria in 1949 were as unsuccessful as my inquiries as to the number in the Law School. I suspect that there were then not many more in the whole College than there are in the Law School now and, as I recall it, the number of freshers who enrolled with me for law were no more than 15 or 20, of whom two I think were women. My memory could be wrong, but not far wrong. One of those freshers was a fellow called Tom Eichelbaum and he at once impressed me as a very diligent fellow indeed, with a much clearer sense of purpose than I had. Only later did I find out why. Some really bright ones (if the former Chief Justice will forgive me) like Robin Cooke were well ahead of us, little more than names to be held in some awe.

Thus in numbers, and in many other respects, it was a far cry from today. But so it was from the day 50 years earlier, in April 1899, when 17 students sat down to hear about Jurisprudence in borrowed quarters in the Technical School and the Girls High School. 
As for us, quite ignorant of the seismological risks to which we were subjected, we had lecture rooms in the Hunter Building and a couple of bays of law books and law reports in the College Library, now the Council Room. The Library was patrolled ceaselessly by a fierce spinster, Miss Isaacs, whose office was to silence even the most whispered conversation. I suppose she was the Deputy Librarian. The Librarian was Harold Miller, an outstanding scholar and, as I was later to discover, a delightful gentleman of the old school. But he was quiet and reserved, with his own work to do, and of him we saw very little. The Library was a grand room, with the magnificent stained glass window to contemplate, so it was in frequent use, and an encircling gangway half way up the wall that enabled the energetic and the scholarly to have access to the less significant books. As I recall it, those included some American law reports, but we made little use of them, or indeed of anything much beyond our set text books, the New Zealand Law Reports, the All England Law Reports, the official reports and, occasionally, some Australian, or perhaps even, rarely, Canadian volumes.

The soon-to-be-published history of the University notes that the law course was "a fearsome array of narrowly technical learning". That may be a little unfair. But certainly apart from some choices with the optional non-legal subjects, the course was clearcut and largely practical. The faculty was divided into two Departments. The Department of Jurisprudence and Constitutional Law was headed by Professor Robert Orr McGechan, father of the present Judge, who was tragically killed in an air accident in 1954. Kingston Braybrooke, who later went to Australia, was senior lecturer. At the head of the Department of English and New Zealand Law was Professor James Williams, who became principal on Hunter's retirement in 1951 and who was then succeeded by the senior lecturer, I D Campbell. George Barton arrived from Cambridge just as I was beginning my first year of an LLM course that I have yet to complete. That was of course no fault of his.

So there was a fulltime staff of four, very ably supplemented by a team of practitioners from the city who came up to teach the more practical subjects like Company Law and Evidence, Civil Procedure and Conveyancing. Colin Aikman, who was to succeed McGechan in 1955, came up from Foreign Affairs to teach us International Law, although he did not succeed in persuading me, for one, that there really was such a thing. It is rather different now, though. And each year the current President of the Wellington District Law Society gave a series of lectures in Professional Ethics, impressing on us the obligations we would owe to the Court and its officers, to our clients whose interests it was to be our privilege to serve and to our fellow practitioners as members together of an honourable profession. Some of that could bear repeating, I suspect. Somewhere in the Constitutional Law class I think, Mr A Eaton Hurley came to tell us about local government. He was a fine elocutionist and liked nothing more than to recite the preamble to the Local Government Act which he considered the finest piece of legislative prose ever. 
In those days the Law School was really a night school. Lectures were mainly at the beginning or end of the day, with perhaps some tucked in at lunchtime. There were few full time students and of them most joined a downtown office after their first year. I was one of the very few who remained full time for three years and have ever been grateful for the opportunities that gave: to pursue an arts degree as well as the LLB and to participate more fully in student life, student politics, the social life of the cafeteria, student societies and so on. The move to full time study has been hugely beneficial.

Victoria was highly political in those days, with communists and socialists dominating the student body and our affiliations with international communist organisations constantly on the agendas of special and general meetings. There was time to launch a true blue monthly publication, but neither the time nor the enthusiasm to keep it going for long. Soon after, though, the Law Review came along, catering for a rather different readership and fully occupying those who were volunteered to write for it.

Latin was compulsory and, until that requirement was abolished in 1953, the Latin class was replete with a sizeable number of slowly ageing would-be lawyers. As well as Latin there was Roman Law, well suited to the dryness of the nonetheless delightful Braybrooke. Both subjects were no doubt good for the intellect, but although I still have a little - a very little - Latin, Roman Law escapes me altogether. Yet it was important, even though we did not necessarily realise it, for it told us something about the need for law and the purpose of law in the development and functioning of a civilised society.

You really had to learn Roman Law from the textbook, but experience has shown that the same need not be true of other basic legal subjects. Yet so much of our learning was the ingesting of textbooks, the teaching a regurgitation of their contents. So it was, as I remember, with the Law of Contract under Professor Williams. He taught from his edition of Sir John Salmond's original work, but failed, at least in this breast, to raise the high degree of interest that came from Salmond's classic work on Torts, now I expect in its umpteenth edition, and as valuable and interesting a text as ever. Torts was made eminently practical and human; it was a long time before contract became so.

By far the liveliest and the most humanly engrossing topic of all was Criminal Law, taught, from Garrow's book, by Ian Campbell. Certainly we had to learn off numerous definitions, but Campbell was an outstanding teacher; clear, concise and stimulating. And of course some of the things we learnt were eye-openers to this lad from a sheltered Methodist Bible Class background. I have since found that most of it was pretty mild stuff compared with the horrors perpetrated by my fellow citizens in more recent years.

McGechan though was the reformer. He went to the United States and was inspired by the case method of teaching. I must say that many of the students were resistant to this innovation. A job in town did not allow much opportunity to study judgments, even less 
to distinguish the lines of reasoning in multiple judgments. Nonetheless, the teachers persevered, and this socratic method has proved its value over the years. McGechan also established the Law Review, the first of its kind, and had the Law Library moved along the corridor to its own room, into which Miss Isaac rarely entered. He was still in his prime when he met his death; it was grave loss for the University.

Let it not be thought that life was all solemnity even for the part-time law student. We had the Law Faculty Club, after all, charged with a variety of responsibilities ranging from moots to stein evenings to an annual dinner to which the women were admitted only in 1954 after a vigorous attack on the established order led by the fearless Shirley Smith, daughter of the Chancellor and later to become the defender of, or the protagonist for, many a noble cause.

I must not continue to reminisce. But it is I think important to remind ourselves of the changes there have been since the 1950s, in the law and, reflecting them, in the Faculty. I recently saw a photograph somewhere of that new Law Library in the Hunter Building. What immediately struck me was not that it was so small, but that of the few students working there most, if not all, wore jackets and ties. Perhaps that fact and the room itself are symbolic of the changes there have been in the law, in the faculty and in the law course itself.

I think it is fair to say that the changes in the Law School's first 50 years had been relatively few. But clearly in the subsequent years they have been great indeed. Judge-made law has expanded vastly, in scope and in content. Statute law has done the same, ten-fold. As one example, my LLM was to be completed with a thesis on administrative law: all of it readily able to be encompassed in a single dissertation. The longer I left it, the more formidable became the task. Now, the topic is vast, the task abandoned. Family law then was simple and basic, largely contained in the Infants Act 1908 and the Destitute Persons Act 1910. Matrimonial property law was virtually non-existent. Now we have a whole jurisdiction devoted to family matters and a whole range of statutes brought within it.

Equity has taken on a new life. In 1949, High Trees ${ }^{1}$ had only recently hit the law reports. Since then, doctrines of constructive, resulting and implied trust have been developed, the concept of unjust enrichment has been fully embraced, the nature of fiduciaries and the obligations placed on them in a wide variety of circumstances have been clarified and expanded.

1 Central London Property Trust v High Trees House Ltd [1947] KB 130. 
The law of contract has blossomed with the assistance of a host of new statutes that have variously clarified or obscured or reformed the common law: Contractual Mistakes, Contractual Remedies, Contract Enforcement, Privity of Contracts, Credit Contracts, Minors Contracts, Fair Trading and so on.

In tort, the categories of negligence continue to expand despite the abolition of personal injury claims. Perhaps I should say their partly illusory abolition, because in some circumstances they are returning under the guise of exemplary damages. Even the replacement, Accident Compensation law, has become a field - perhaps a minefield - all of its own. So have employment law, immigration law and environmental law, each giving rise to specialist courts and tribunals and thus greatly expanding the range of professional practice. The Legislature has tackled defamation and (to sneak in another two years) contributory negligence.

Of course, people still commit the same range of criminal acts but there are more of them and they are bloodier, while the gravity of sexual crimes has been accorded much greater recognition in both statute and punishment. We have decriminalised homosexual acts between consenting adults, but have had to introduce significant punitive legislation to deal with the new menace of drugs. Surveillance techniques, once unimaginable, are now commonplace.

Then there has been the New Zealand Bill of Rights Act 1990, setting some basic standards of legislative and administrative conduct, achieving greatest practical significance as a shield for offenders, but also beginning to suggest itself as a weapon for those wrongly done by at the hands of the State or its agencies. A side effect of the Bill of Rights has been the more frequent need to open the pages of Canadian Law Reports, even United States reports and those of other jurisdictions as well, such as India, to say nothing of the international and other human rights documents.

Since 1949 too, we have seen a renaissance of Maoridom and with it we have rediscovered the Treaty of Waitangi. We have had to understand what it meant and what it means, we have established procedures for inquiring into claims of breach and for seeking to redress injustices. Questions of customary law and indigenous title have arisen which would never have occurred to any but the most far-thinking lawyer in 1949.

The status of the Treaty has become central to many of the more recent constitutional issues that have emerged, but there have been many earlier constitutional developments. New Zealand adopted the Statute of Westminster only in 1947 and it was not until 1986 that we enacted our own Constitution Act, thus, in the words of Lord Cooke of Thorndon, cutting the painter that had tied New Zealand constitutional law to United Kingdom origins. In 1950, without more than a couple of blinks, we abolished an Upper House in favour of the rarity of a unicameral Legislature. In 1962, we created the office of 
Ombudsman and 20 years later we had our Official Information Act. And now we have Mixed Member Proportional Representation (MMP), its ramifications opening wide new fields of scholastic endeavour.

Human rights, privacy, occupational safety and health have all made their own particular contribution to the proliferation of statute law and often of administrative and other Tribunals.

And of course our internal arrangements and our domestic law have been profoundly affected by our external relations and our place in the community of nations. International human rights law is more and more influencing our own, while the need for harmonisation in areas such as commerce and trade and intellectual property is becoming increasingly apparent. We have even got to the point of cooperating with our neighbours across the Tasman in the conduct of civil litigation.

Great change there has been then, in the past half century, a great deal of it in fact in the second half of that half - as much, probably more, in that 50 years than in any similar period in our legal history. We might well wonder whether the two instruments of change, Parliament and the Courts, may not have run out of steam. But there is probably no danger of that. After all, that is why we have a Law Commission. To some extent, the rate and the nature of future change will depend on political philosophy, on the extent to which we are to be regulated or protected from ourselves and from others. But even so, over our shoulders will always be the wider world beyond our shores, reminding us of our increasing globalisation, of the need for harmonisation. I have mentioned the need for effective compliance with our international obligations, suggesting even some self interest in promoting New Zealand not just as a reliable and predictable trading partner, but even as suitable neutral ground for the resolution of international disputes.

And ever pressing on us, for the exercise of wise and sensible and practical judgement, will be the scientists. They have been making their mark on the practice of the criminal law with some remarkable investigative techniques, and now we have the mighty wonder of DNA matching: at present for better and for worse, but before long, I am sure, entirely for the better. It is a thought that a greater investment in perfecting techniques may soon result in a considerable fall-off in criminal legal aid expenditure. Legal aid itself is of course another of the major developments in the past half century.

But to come back to the scientists. Information and communications technology are I suppose still in their childhood and will be throwing up a host of problems that most of us cannot even imagine; while the biologists and the chemists are away ahead of both law and ethics in reproductive technology in plant and animal genetics, and no doubt in other respects too, which I cannot comprehend. 
The law is also going to have to encompass Maori aspirations. The jurisdiction of the Waitangi Tribunal does not go back far enough, nor are its powers extensive enough for many in Maoridom. Nga Puhi, for example, want to go back to 1815 and to reclaim privately owned land. The demand for rangatiratanga is growing more insistent. It cannot be ignored or kept indefinitely in the too-hard basket. A means must be found of giving effect to it within the modern multicultural nation we have become.

These are some pretty obvious areas in which the law will, I am sure, develop in the years immediately ahead. The very nature of them suggests the role a law school must play. For they are difficult areas, requiring sound and dispassionate judgement and a clear appreciation of what law is for; what part it plays in society.

A law school is of course committed to the essential purposes of a University - the development of intellectual independence, the role as critic and conscience of society. Its academic staff have an unparalleled opportunity themselves to further those purposes. But primarily it furthers them in the training of lawyers, and by that I mean not only the inculcation of legal knowledge and skills, for that is hardly enough to assure intellectual independence. I mean too the development of those perceptions and understandings that will enable lawyers to contribute usefully, and with community acceptance, to the shaping of the law and to the major social issue of the day.

This means that the law course must be much broader than the technical subjects. Indeed, one wonders whether they may not even now be overdone, especially as more and more students take a law degree as a qualification for some other occupation. Basic principles of course must be understood, but much of the detail is of value only to the practitioner; and even to him or her change is so frequent that it may be necessary only to know where and when to look for the detail.

More important, I suggest, is an understanding of society and of the role of the law and of lawyers in it. There has been a tendency in the past to see law simply as an affirmation and guardian of individual rights, and some effort has gone into making sure various sectors of the community know what their rights are. Maybe there has not been enough emphasis on the other side of the coin, the responsibilities of citizenship. But of course there is a great deal more to it than that, for law affects life in all its facets. I know that this School has recognised that, in the great expansion of optional subjects it makes available.

I wonder though whether some of these should not be made obligatory. One example is the ethics course that the Dean told me about the other day, which goes far beyond the professional ethics course of old and confronts the student with some of the wider ethical problems that law makers as well as law practitioners are going to have to grapple with. Another topic which could well be compulsory is economics, of which I know very little, but about which I have no doubt Sir Ivor Richardson will be saying something. Then there 
is our own nation's history, about which most of us are still pretty ignorant, but which is surely an essential background for dealing with the Treaty-related issues that are likely to become more and more prominent. And I would most certainly make English language and literature obligatory, if only to eliminate the misuse of the apostrophe.

Lawyers are often required to argue questions of public interest and public policy and Judges are required to decide them. How well equipped are any of us to undertake those responsibilities if all we know are the legal rules? The law lies at the very heart of society and those who practise it, in whatever capacity, must assuredly know what they are doing and why: it is not simply to earn large incomes.

May I in conclusion, and to impress on the Dean and his colleagues the grave responsibility that is theirs, quote from an American writer, whose name I do not know:

When I was in the sixth grade and our family had just moved up to the housing projects, we went to Mrs Shelton's class and she was writing these long words on the board. We kept saying "This is the 6th grade. Not the 8 th". And she turned round and said:

I know what grade this is, I work here. These are no longer big words, these are polysyllabic terms, and over here's a dictionary and a Roget's Thesaurus, and right down the hall is a library, and there's something called the Dewey system. I will never teach down to you. One of you little brats might run for governor or president one day, and I don't want to be found guilty.

I can only hope that no-one here today feels guilty. 
